\title{
FATIGUE AND CORROSION PHENOMENON ON FAILURE OF WATER WALL TUBE BOILER
}

\section{FENOMENA FATIK DAN KOROSI PADA KERUSAKAN PIPA KETEL UAP BAGIAN WATER WALL}

\author{
Eka Febriyanti ${ }^{\mathrm{a}}$, Amin Suhadi $^{\mathrm{a}}$, Laili Novita Sari ${ }^{\mathrm{a}}$ \\ a Balai Besar Teknologi Kekuatan Struktur (B2TKS), Badan Pengkajian dan Penerapan Teknologi \\ (BPPT), PUSPIPTEK, Serpong, 16314, Indonesia \\ e-mail: eka.febriyanti@bppt.go.id, amin.suhadi@bppt.go.id, laili.novita@gmail.com
}

\begin{abstract}
Water wall tube is one component of a steam boiler which has a function to transform water to vapour, and hence it is commonly called the steam generating tubes. Any failures on the wall tube will affect the whole boiler system. The purpose of this research is to find out root the cause of failures of a wall tube in order to avoid similar case in the future. The research was conducted by examining and testing the specimens on various aspects including visual, fractography, metallography, chemical analysis, hardness test and tensile test. Examination on the fracture surface by fractographic method found the evidence of fatigue fracture with the presence of beach mark. Another examination on uninstalled boiler tube showed indication of fabrication defect and trans-granular cracks which allowed corrosive agent infiltrated into the microstructure of the tube. However, the result of chemical analysis and tensile test indicated that the tubes investigated were in accordance with ASTM A 210 Grade C specifications. Therefore, the failure of the tube was not caused by wrong material selection, but rather by combination of fatigue fracture and corrosion attack which were initiated at fabrication defect that subsequently acted as stress raisers.
\end{abstract}

Key Words: Water wall, Tube boiler, Fabrication defect, Fatigue, Crack, Corrosion

\begin{abstract}
Abstrak
Water wall tube merupakan salah satu komponen ketel uap yang berfungsi untuk memanaskan air menjadi uap sehingga sering disebut sebagai steam generating tubes. Jika wall tube mengalami kebocoran maka seluruh sistem pada ketel uap tersebut akan terganggu atau bahkan mengalami kegagalan. Penelitian ini bertujuan untuk mencari penyebab utama suatu kasus perpatahan suatu komponen wall tube, agar kerusakan yang serupa tidak terulang. Penelitian dilakukan dengan berbagai pemeriksaan dan pengujian meliputi pemeriksaan visual dan fraktografi, metalografi, analisa komposisi kimia, uji kekerasan material, dan pengujian tarik. Hasil penelitian fraktografi menunjukkan adanya indikasi perpatahan akibat pembebanan fatigue berupa beach mark. Selain itu hasil pemeriksaan metalografi material wall tube boiler yang belum terpasang didapat cacat fabrikasi, dan retak transgranular yang menyebabkan media korosif masuk ke dalam struktur mikro tube. Hasil analisa komposisi kimia dan hasil pengujian tarik pada wall tube baik yang
\end{abstract}


patah maupun yang belum terpasang sesuai dengan spesifikasi standar ASTM A 210 Grade C. Jadi, mekanisme perpatahan pada wall tube bukan disebabkan oleh kesalahan material namun disebabkan karena kombinasi antara patah fatigue dan serangan korosi yang diawali pada daerah cacat fabrikasi yang berperan sebagai pengumpul tegangan.

Kata Kunci: Water wall, Tube boiler, Cacat fabrikasi, Fatigue, Retak, Korosi

Diterima (received): DD MMM YYY, Direvisi (revised): DD MMM YYY, Disetujui (accepted): DD MMM YYY

\section{INTRODUCTION}

When a power plant shut down due to failure of its components, potential financial loss will be very high. Therefore, any failure of components should be analysed as soon as possible to reduce cost and to prepare solution actions to prevent further problems. This problem often occurs on power plants especially steam power plant.

This research observes the failure of steam power plant components called water wall tube boiler which was broken in a position as shown in Figure 1.

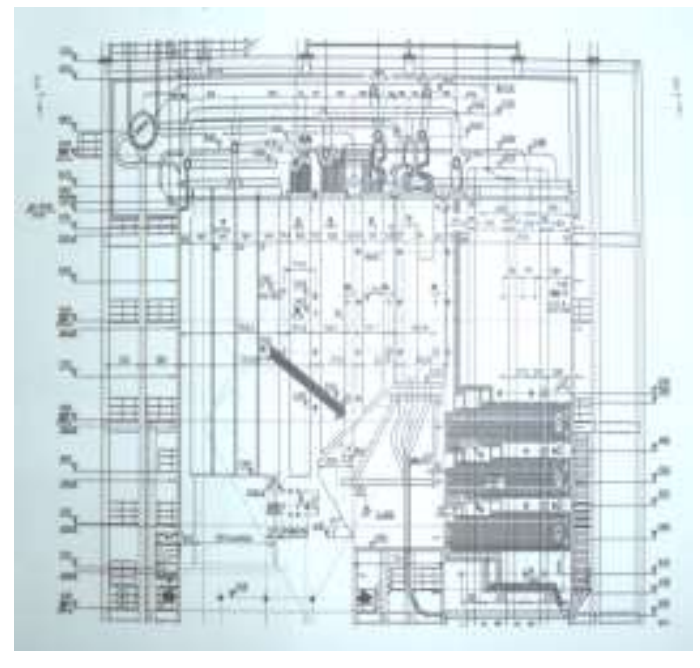

Figure 1.

Position of water wall tube in a steam boiler

Process of steam generation in a boiler is initiated by flowing feedwater to economizer where water is heated by hot gas. In economizer, the water is transformed into vapor, and then this vapor is flown into steam drum. Subsequently the wet vapor flows to water wall tube to be reheated into steam, hence the water wall tube is often called Steam Generating tubes as shown in Figure 2. Because tubes are installed side by side like a wall so that this boiler component is called water wall tubes and sometimes called water wall panels. These tubes constructions are complicated structures, as a result routine inspection are difficult to perform ${ }^{1)}$.

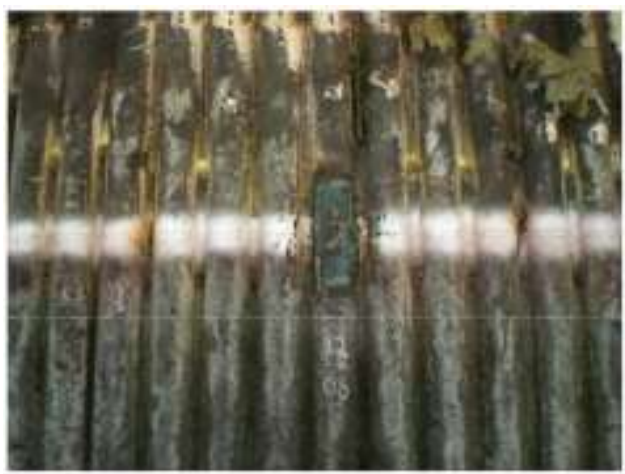

Figure 2.

Water wall tube construction in a boiler

The purpose of this research is to find out root cause of failure on water wall tube in a boiler and to provide recommendations in order to prevent similar failure in the future.

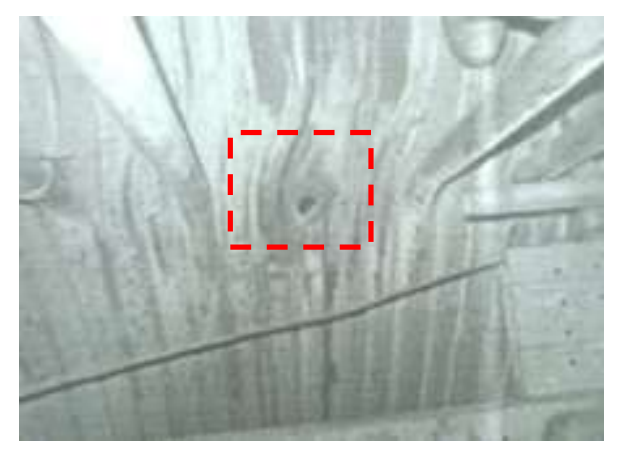

Figure 3.

Position of failure wall tube in boiler (red dot square)

\section{MATERIALS AND METHODS}

The specimens were taken out on site from the failed water wall tubes as shown in Figure 3. The Water wall tube is normally made of 
intermediate carbon steel in ASME standard specification Section II Part D Grade C ${ }^{2)}$. Technical data and operational data are listed in Table 1.

Table 1.

Technical data of Water Wall Tube

\begin{tabular}{ll}
\hline Tube Material & SA 210 Grade C \\
\hline Operation Temp $\left({ }^{\circ} \mathrm{C}\right)$ & 450 \\
Design pressure $\left(\mathrm{kg} / \mathrm{cm}^{2}\right)$ & 157,4 gauge \\
OD $\varnothing$ tube $(\mathrm{mm})$ & 72 \\
Tube thickness $(\mathrm{mm})$ & 6,5 \\
Application & $\begin{array}{l}\text { Steam power } \\
\text { plant }\end{array}$ \\
\hline
\end{tabular}

This research is conducted based on "root cause analysis method" where all possible sources that has contribution to failure are observed. And then the main factor which is most dominant is further examined. The schematic flow diagram of research steps is shown in Figure 4.

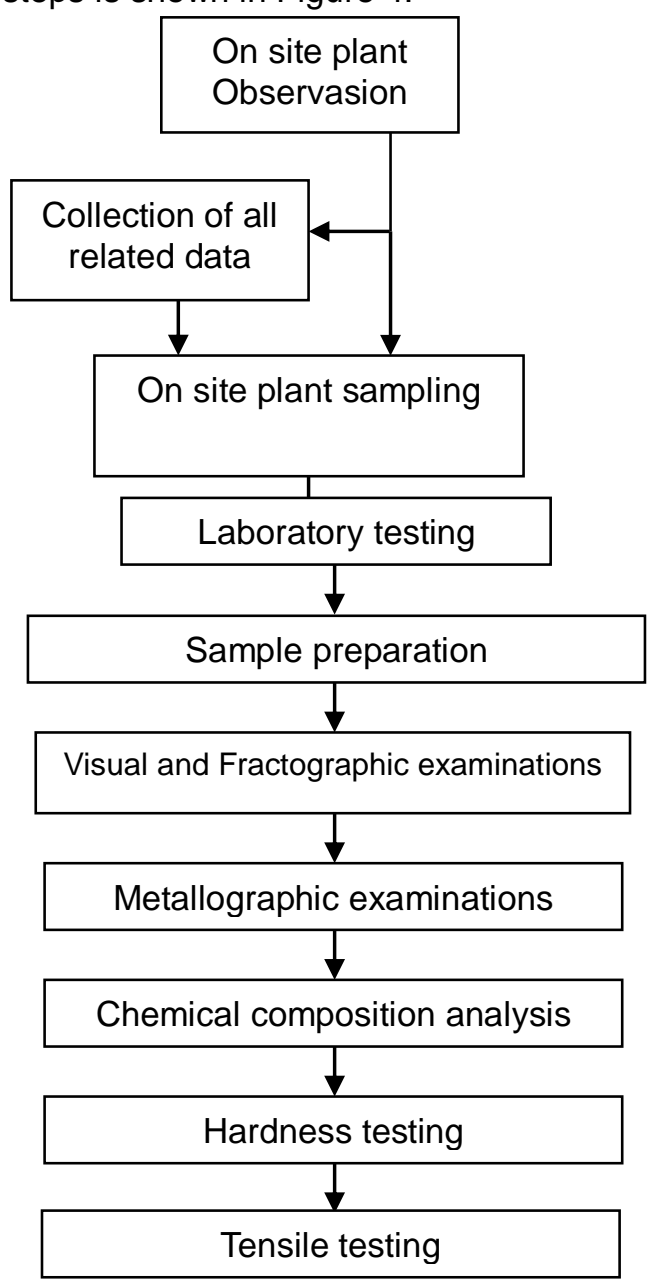

Figure 4

Schematic flow diagram of examinations and tests on the specimen investigated

\section{RESULTS AND DISCUSSIONS}

\section{Research Results Visual and Fractographic Inspection}

Visual and fractography examination result show that water wall tube of a boiler investigated is broken perpendicular to tube axis and the fracture location is around weld area (Figure 5). Moreover, it is also found a sharp failure tip on surface fracture of the tube at welded area (doted circle on Figure 6), and this area is identified as initial fracture. Further observation on fracture surface on other area also found the track of crack propagation caused by dynamic loading, which is normally called fatigue fracture (Figure 7). This evidence is unique, consists of smooth and rough area and only appear caused by fatigue fracture. There is no any other kind of fracture can produce this evidence ${ }^{3)}$. Smooth area represents crack propagations during dynamic load, usually marked with row of curve line that is named "beach mark" ${ }^{4}$. On this specimen, beach marks are identified as about $35 \mathrm{~mm}$ length from the point of initial propagation (Figure 7-9). Rough surface indicates residual fracture, where sudden brake occurs because the remaining cross section is no longer able to support the applied load. Residual fracture surface usually has contours angle of about $45^{\circ}$ to the tube axis (Figure 10) ${ }^{4}$.

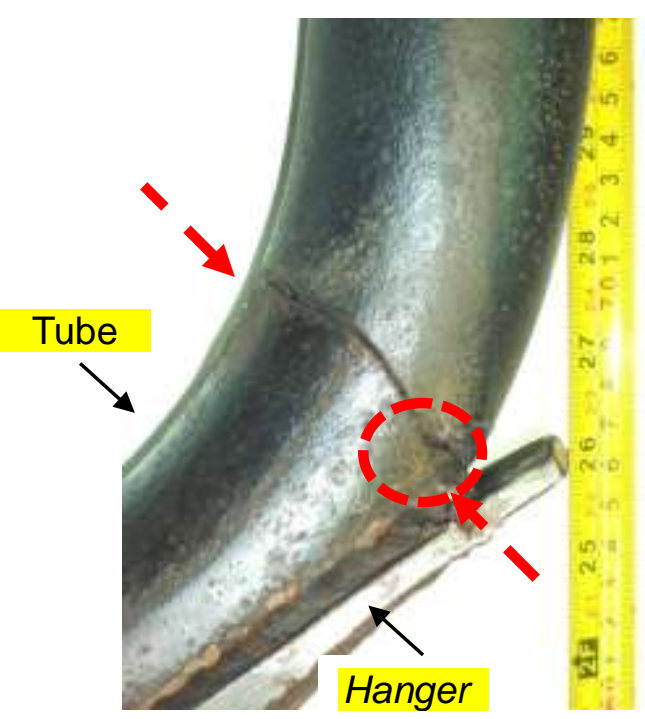

Figure 5.

Position of failure on wall tube boiler 


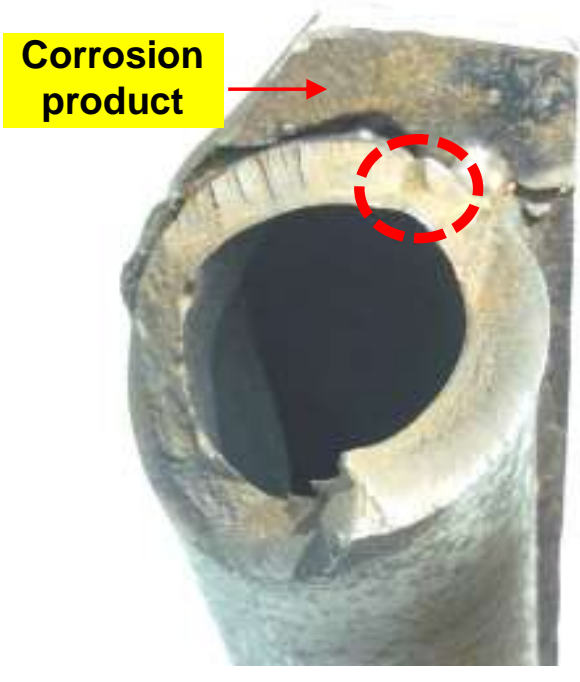

Figure 6.

Sharp failure tip on weld area of surface fracture of tube boiler investigated

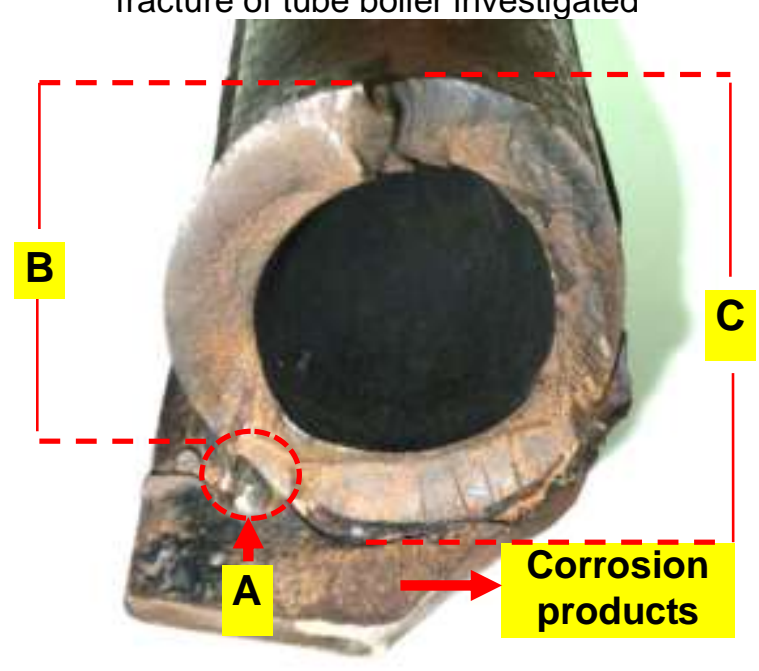

Figure 7.

Surface fracture of wall tube boiler shows evidence of fatigue fracture, consist of $(A)$ initial crack area, (B) crack propagation area, and $(C)$ residual fracture area

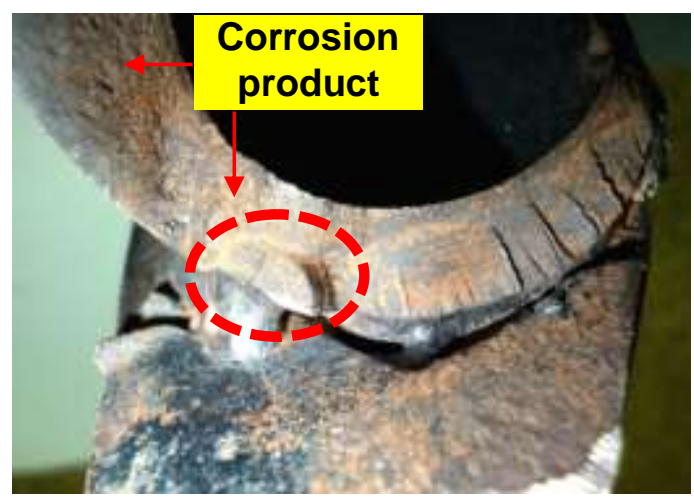

Higher magnification on initial crack area (A area on Figure 7).

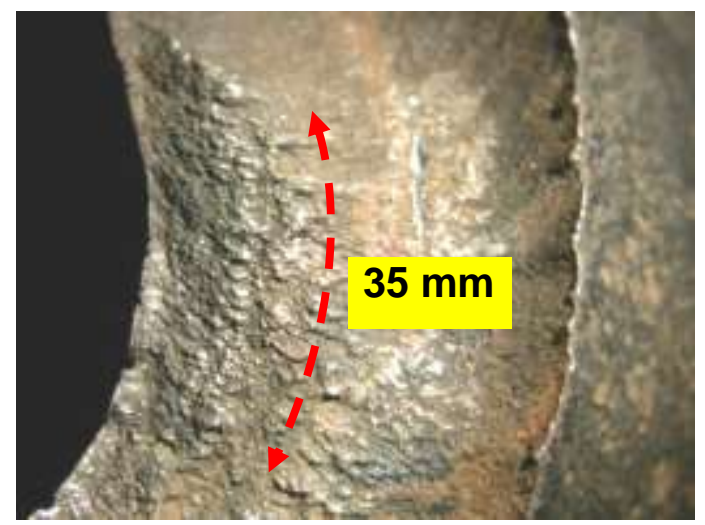

Figure 9.

Higher magnification on crack propagation area (B on figure 7) shows beach marks

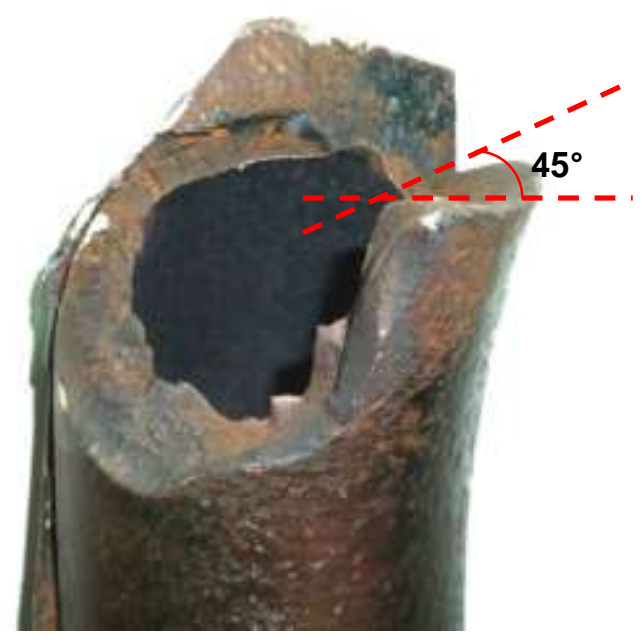

Figure 10.

Higher magnification on residual fracture area (C-on figure 7) shows fracture contour that has $45^{\circ}$ angel to tube axis.

As a comparison, a specimen is also taken from un-installed tube which still in good condition (Figure 11).

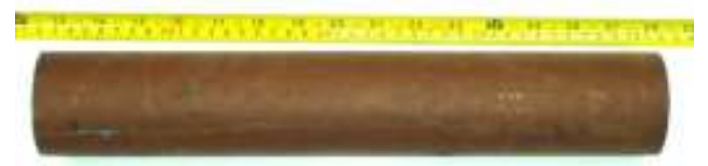

Figure 11.

Un-installed tube boiler for comparison analysis

Figure 8. 


\section{Metallographic Examination}

Three specimens are taken from different area on the water wall tube for metallographic examinations as shown on Figure 12. The specimens are then identified as specimen no.1, 2 and 3 .

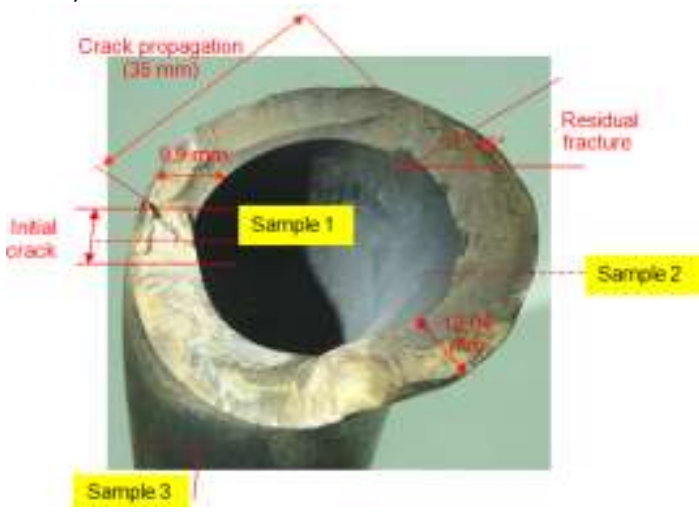

Figure 12.

Location taken for metallographic specimens

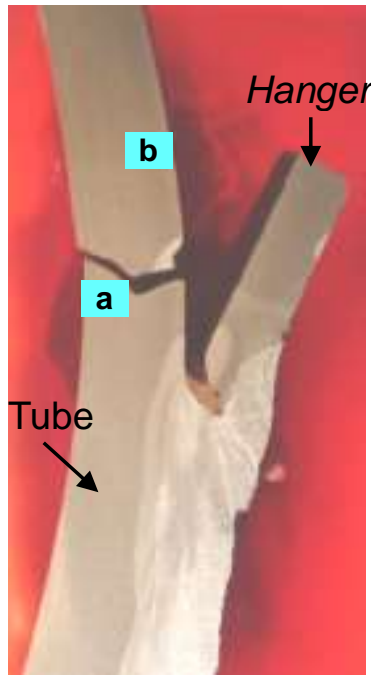

Figure 13.

Metallographic result on specimen number 1.

(a) and (b) are location for further exposed

Microstructure of base metal both on fracture area (location-a) and away from fracture area (location-b) is a mixture of ferrite and pearlite (Figure 14 and 15). This is a normal microstructure of carbon steel material. Metallographic examinations result also shows that trans-granular cracks are exist in both areas. Those cracks produce corrosion agent entering into the structure and then corrosion reaction may occur.

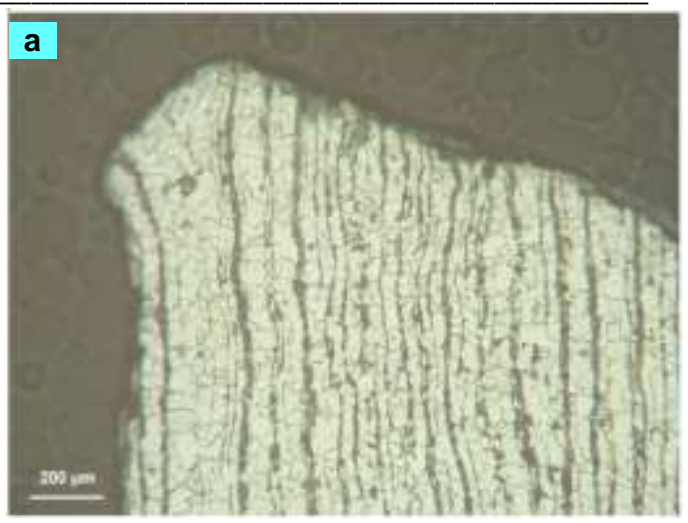

Figure 14

Microstructure of base metal (specimen 1 location-a) consist of a ferrite-pearlite mixture.

Etched by: $2 \%$ Nital

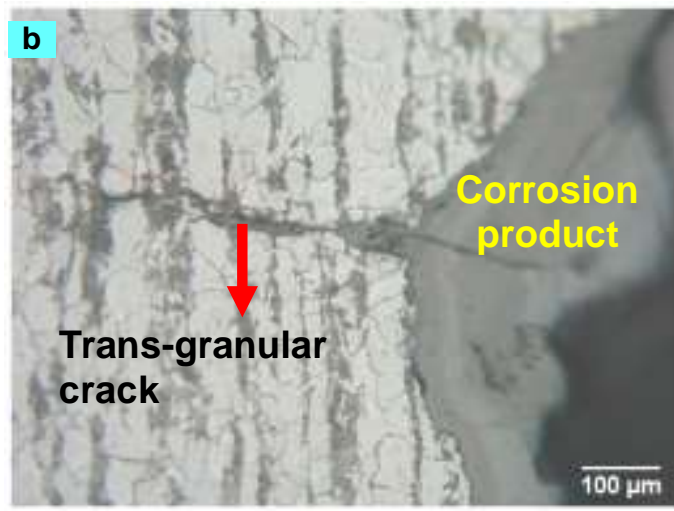

Figure 15.

Microstructure of base metal (specimen1 location-b) consist of ferrite-pearlite mixture. Trans-granular crack is observed as filled by corrosion product. Etched by: $2 \%$ Nital

Specimen number 2 is taken on weld area between tube and hanger (Figure 16). Microstructure of this area is bainite and a macro crack is observed, propagated from weld area to base metal (Figure 17). 


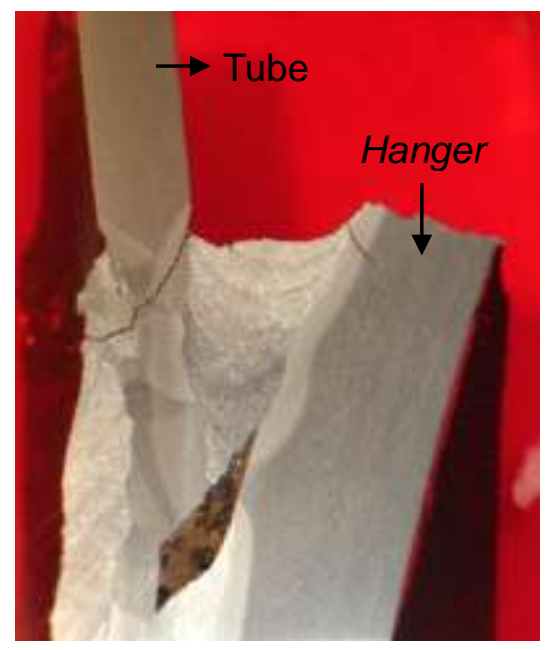

Figure 16.

Specimen number 2 for metallographic examination

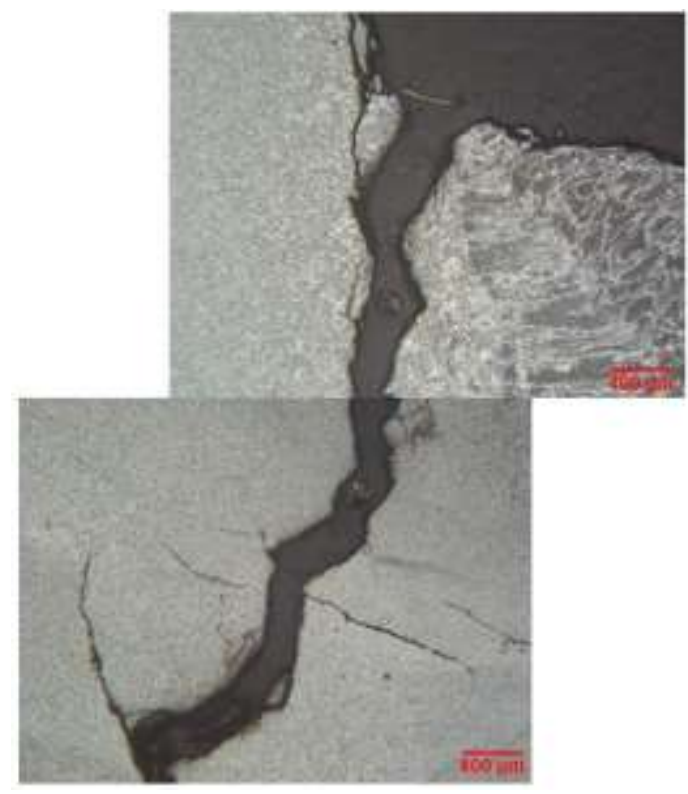

Figure 17.

Macro crack is found on weld area and propagated into base metal. Etched by: $2 \%$ Nital

Specimen number 3 is taken away from surface fracture (Figure 18). Microstructure of this area is a mixture of ferrite and pearlite (Figures 19-20). Metallographic examination on this area also found micro crack on base metal (Figure 20).

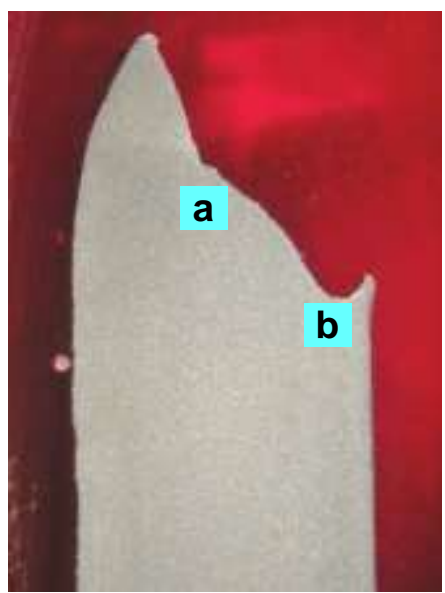

Figure 18.

Specimen number 3 for metallography examination

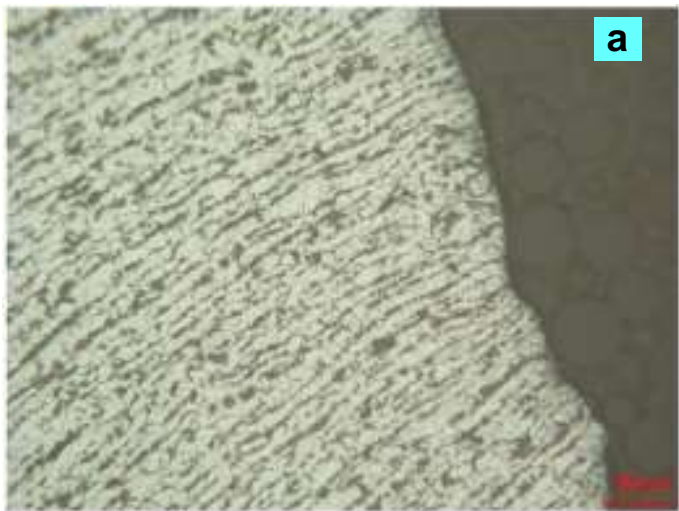

Figure 19.

Microstructure of base consist of a mixture of ferrite and pearlite. Etched by $2 \% \mathrm{Nital}$

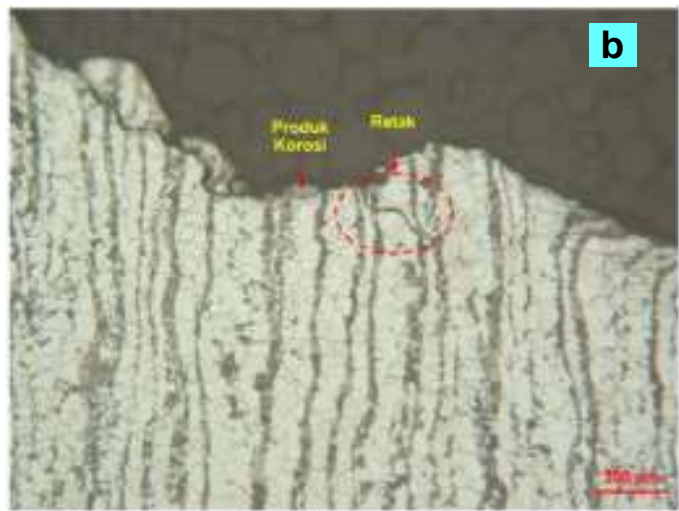

Figure 20.

Microstructure of base metal in other area consist of a mixture of ferrite and pearlite. Micro crack is also found in this area. Etched by $2 \% \mathrm{Nital}$ 
Specimen number 4 is taken from cross section of un-installed water wall tube which is still on good condition (Figure 21). Microstructure of this specimen is a mixture of ferrite and pearlite like microstructure of other specimens. However, this specimen shows a small manufacturing defect in the structure (Figure 22-23). The defects are formed like a small hole and the microstructure grain boundary is following this contour ${ }^{5)}$. This small hole is also filled with corrosion products (Figure 22-23).

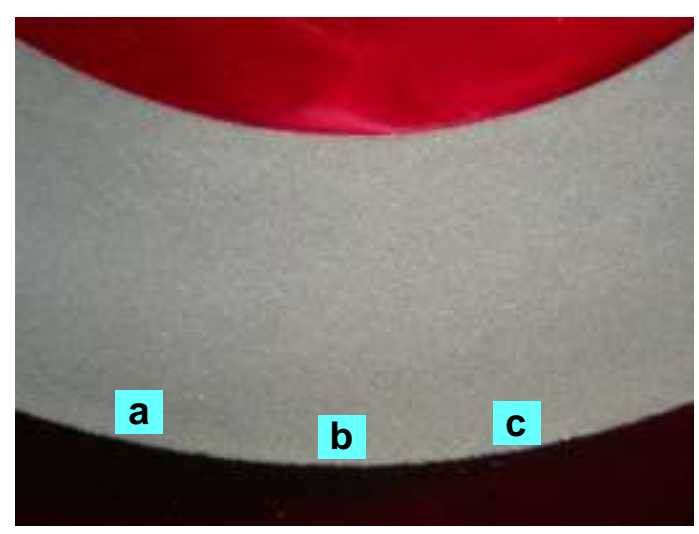

Figure 21.

Specimen no 4 for metallographic examinations

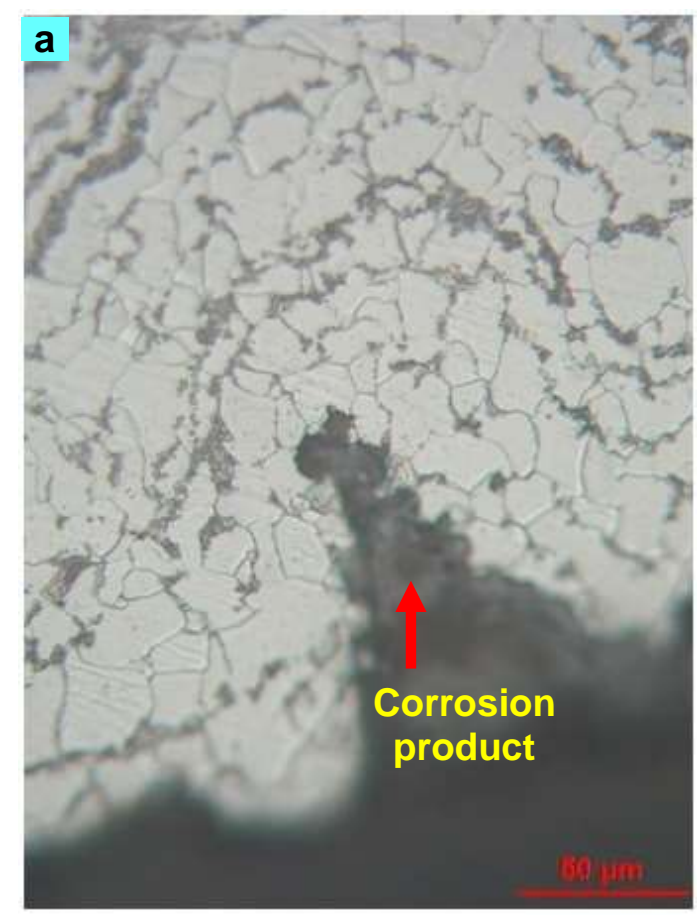

Figure 22.

Microstructure of un-installed tube consist of ferrite and pearlite. Small manufacturing defect is found and filled by corrosion product. Etched by $2 \%$ Nital

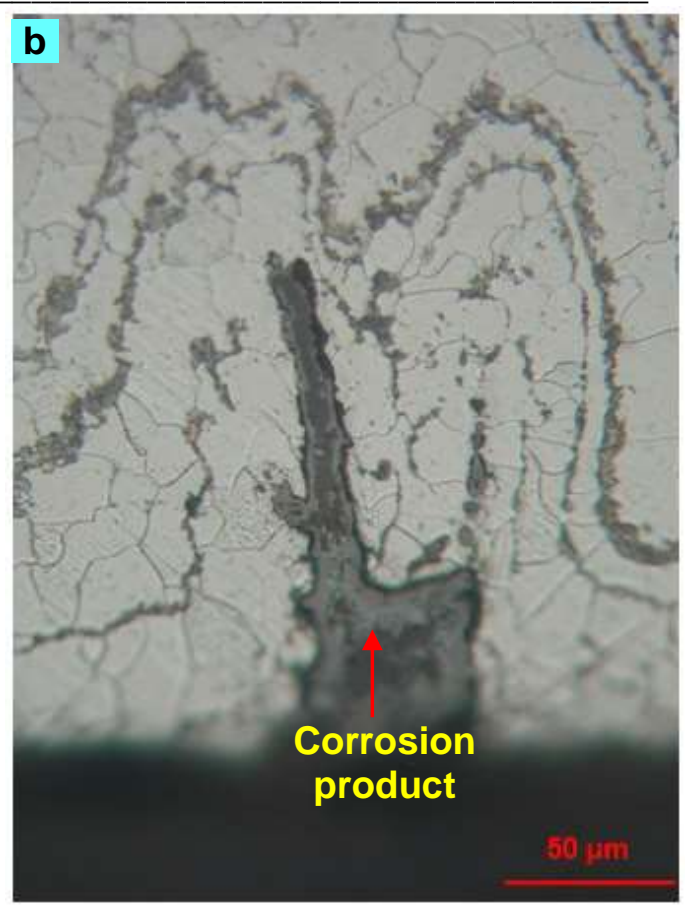

Figure 23.

Defect on other area (b), grain boundary of structure is following the contour of manufacturing defect. Etched by $2 \% \mathrm{Nital}$

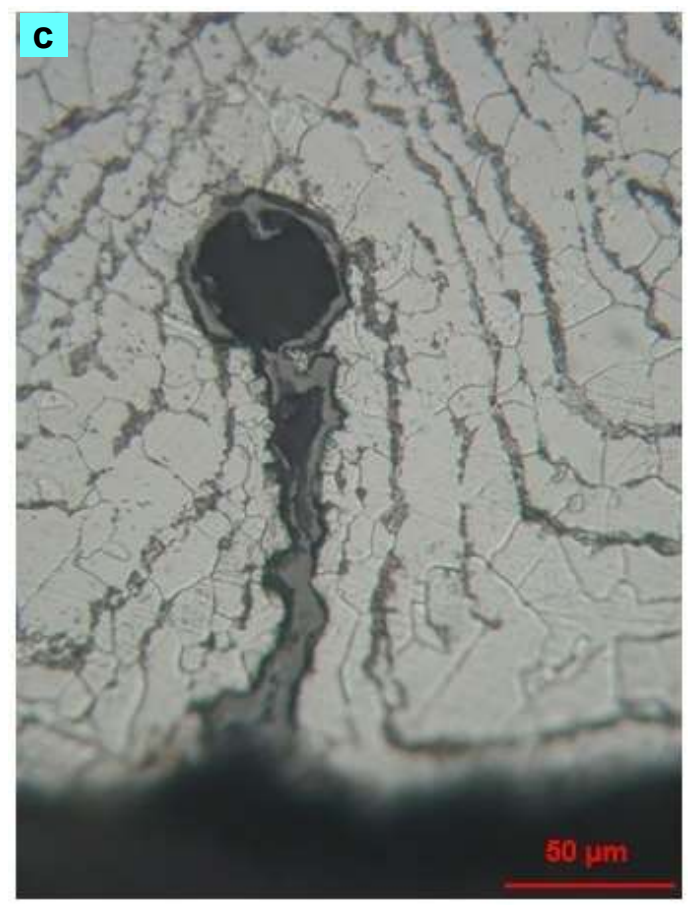

Figure 24.

Defect on other area (c), grain boundary of structure is following the contour of manufacturing defect. Etched by $2 \% \mathrm{Nital}$ 


\section{Chemical Composition Analysis}

Specimen for chemical analysis is taken from both failure tube and un-installed tube. Result of chemical test is shown in Table 2 and 3 . Those tables indicated that each tube has similar composition and in accordance with ASTM A 210 Grade C ${ }^{6)}$ specification.

Table 2.

Result of chemical test on failure tube

\begin{tabular}{ccc}
\hline Element & $\begin{array}{c}\text { Tube } \\
\text { (wt \%) }\end{array}$ & $\begin{array}{c}\text { ASTM A 210 } \\
\text { Grade C }\end{array}$ \\
\hline $\mathrm{Fe}$ & Rem. & - \\
$\mathrm{C}$ & 0,240 & 0,35 max. \\
$\mathrm{Si}$ & 0,314 & 0,10 min. \\
$\mathrm{Mn}$ & 0,924 & $0,29-1,06$ \\
$\mathrm{Cr}$ & 0,0245 & - \\
$\mathrm{Ni}$ & 0,0088 & - \\
$\mathrm{S}$ & 0,0046 & 0,035 max. \\
$\mathrm{P}$ & 0,0176 & 0,035 max. \\
\hline
\end{tabular}

Table 3.

Result of chemical test on un-installed tube

\begin{tabular}{clc}
\hline Element & $\begin{array}{l}\text { Tube } \\
\text { (wt \%) }\end{array}$ & $\begin{array}{c}\text { ASTM A 210 } \\
\text { Grade C }\end{array}$ \\
\hline $\mathrm{Fe}$ & Rem. & - \\
$\mathrm{C}$ & 0,261 & $0,35 \mathrm{max}$. \\
$\mathrm{Si}$ & 0,276 & $0,10 \mathrm{~min}$. \\
$\mathrm{Mn}$ & 0,874 & $0,29-1,06$ \\
$\mathrm{Cr}$ & 0,022 & - \\
$\mathrm{Ni}$ & 0,0074 & - \\
$\mathrm{S}$ & 0,0044 & 0,035 max. \\
$\mathrm{P}$ & 0,0169 & 0,035 max. \\
\hline
\end{tabular}

\section{Hardness Testing}

Hardness testing result on cross section of tubes is shown in Table 4 and Table 5 and location of indentation is shown in Figure 25 and Figure 26.
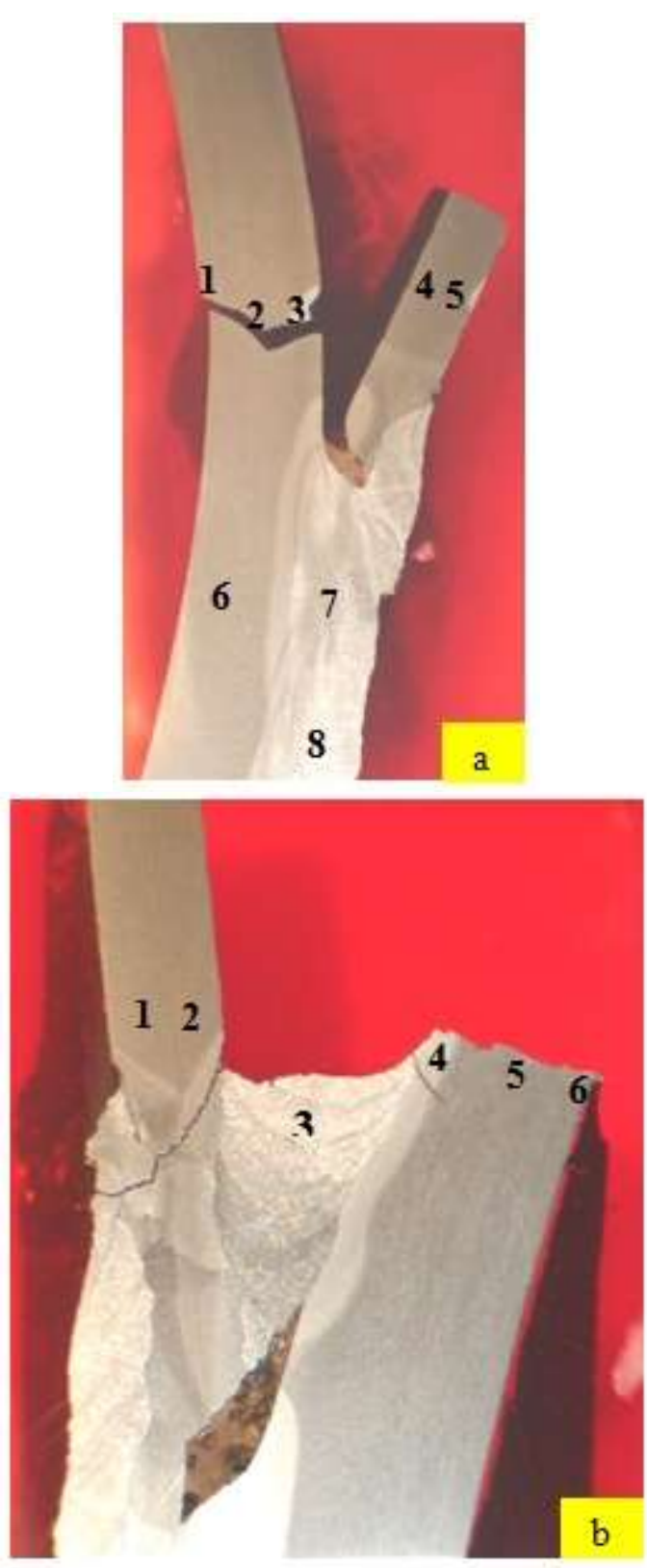

Figure 25.

Specimen for hardness test of failure tube around failure area

Table 4.

Hardness test result of failure tube on specimen $\mathrm{a}$ and $\mathrm{b}$ around failure area

\begin{tabular}{ccc}
\hline No. & \multicolumn{2}{c}{ Hardness Vickers } \\
& a & bV) \\
\hline 1 & 210 & 156 \\
2 & 208 & 165 \\
3 & 271 & 254,5 \\
4 & 167,5 & 243,5 \\
5 & 162,5 & 188 \\
6 & 201,5 & 192 \\
7 & 202 & \\
8 & 220,5 & \\
\hline
\end{tabular}




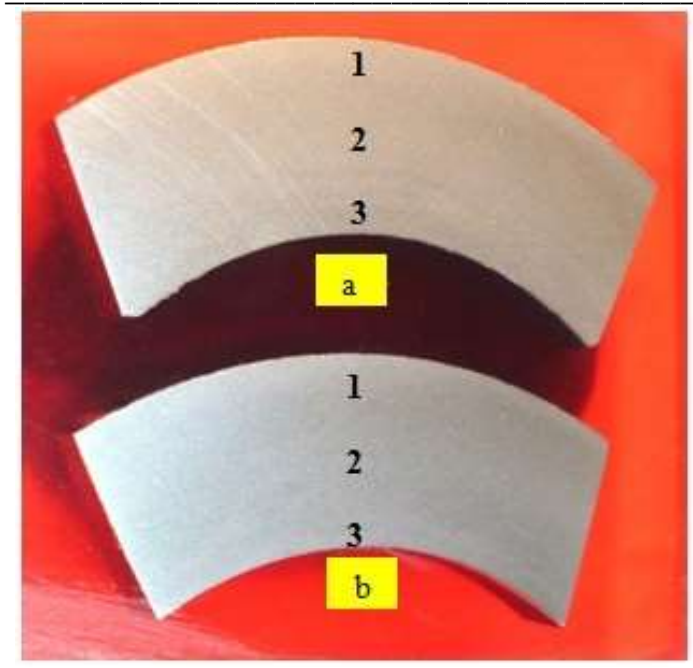

Figure 26.

Hardness test specimen on cross section of failure tube and un-installed tube away from failure area

Table 5.

Hardness test result of un-installed tube and failure tube away from failure area

\begin{tabular}{ccc}
\hline \multirow{2}{*}{ No. } & \multicolumn{2}{c}{$\begin{array}{c}\text { Hardness Vickers } \\
\text { (HV) of tube }\end{array}$} \\
\cline { 2 - 3 } & Un-installed & Failure \\
\hline 1 & 165 & 170,5 \\
2 & 156 & 161 \\
3 & 153 & 156 \\
Average & 158 & 162,5 \\
\hline
\end{tabular}

\section{Tensile Test Result}

Result of tensile test of failure tube can be seen in Table 6, while the result of un-installed tube can be seen in 7 .

Table 6.

Tensile test result of failure tube

\begin{tabular}{cccccc}
\hline No & & & & & \\
$\cdot$ & UTS & UTS & YS & YS & $\varepsilon$ \\
& Spc & $\begin{array}{c}\text { Std } \\
\mathrm{N} / \mathrm{mm}^{2}\end{array}$ & $\begin{array}{c}\text { Spc } \\
\mathrm{N} / \mathrm{mm}^{2} .\end{array}$ & $\begin{array}{c}\text { Std } \\
\mathrm{N} / \mathrm{mm}^{2}\end{array}$ & $\begin{array}{c}\mathrm{N} / \mathrm{mm}^{2} \\
\%\end{array}$ \\
\hline 1 & 498 & & 361 & & 20 \\
2 & 486 & $\mathbf{4 8 5}$ & 318 & $\mathbf{2 7 5}$ & 34 \\
3 & 507 & Min & 350 & Min & 24 \\
Av & $\mathbf{4 9 7}$ & & $\mathbf{3 4 3}$ & & $\mathbf{2 6}$ \\
\hline
\end{tabular}

\section{Remark:}

UTS Spc = Ultimate Tensile Stress specimen UTS Std $=$ Ultimate Tensile Stress Standard ASTM A 210 Grade C

YS Spc = Yield Stress specimen YS Std = Yield Stress standard ASTM A P-ISSN 1410-3680 / E-ISSN 2541-1233

$$
\begin{aligned}
& 210 \text { Grade } \mathrm{C} \\
& \varepsilon \quad=\text { Elongation }
\end{aligned}
$$

Table 7.

\begin{tabular}{|c|c|c|c|c|c|}
\hline No. & $\begin{array}{c}\text { UTS } \\
\text { Spc } \\
\mathrm{N} / \mathrm{mm}^{2}\end{array}$ & $\begin{array}{l}\text { UTS } \\
\text { Std } \\
\mathrm{N} / \mathrm{mm}^{2}\end{array}$ & $\begin{array}{c}\mathrm{YS} \\
\mathrm{Spc} \\
\mathrm{N} / \mathrm{mm}^{2}\end{array}$ & $\begin{array}{c}\mathrm{YS} \\
\mathrm{Std} \\
\mathrm{N} / \mathrm{mm}^{2}\end{array}$ & $\varepsilon$ \\
\hline 1 & 504 & & 347 & & 14 \\
\hline 2 & 495 & 485 & 342 & 275 & 16 \\
\hline 3 & 515 & Min & 350 & Min & 32 \\
\hline Av & 504 & & 346 & & 31 \\
\hline
\end{tabular}

Tensile test result of un-installed tube

Remark:

UTS Spc = Ultimate Tensile Stress specimen UTS Std = Ultimate Tensile Stress Standard ASTM A 210 Grade C

YS Spc = Yield Stress specimen

YS Std = Yield Stress standard ASTM A 210 Grade C

$$
\varepsilon=\text { Elongation }
$$

Tensile test result indicated that both tubes (failure tube and $d d \quad b$ bvgid vbyyyju6un-installed tube) have tensile test in accordance with ASTM A 210 Grade C ${ }^{6)}$ standard.

\section{Discussions}

Result of chemical composition and tensile test indicated that failure tube and un-installed tube are in accordance with ASTM A 210 Grade $C^{6)}$ specification, therefore failure of this water wall tube is not caused by wrong material selection.

From fractography and metallography result show that the type of fracture is fatigue fracture which is indicated by the presence of beach mark on the fracture surface (Figure 7-9 $)^{3)}$. Moreover, it is also found corrosion product on the fracture surface (Figure 6-8), so that it can be confirmed that the main cause of failure is a combination of fatigue fracture and corrosion attack. Fatigue crack can be generated when dynamic load is operated during operation. In this tube boiler, dynamic load can occur when the tube is vibrated due to improper tightening by the hanger. Especially when fluid flows through the bended tube, the change of flow direction gives significant energy to vibrate. This vibration last very long time, so that with the presence of manufacturing defect (Figure 22-24) which acted as stress raiser or welding that also produces residual stress, crack will start to form and then propagated until the tube broken. As 
the crack started to form, corrosive agent may infiltrate into the tube material and reacts with base metal to produce rust 7,8 . As a result, crack propagation running faster and faster until the remaining tube strength is no longer support the operational load, and finally the tube break. The fact that boiler is operated at relatively high temperature, this condition can accelerate corrosion reaction, so that crack propagation is also speeded up until the tube break. The fact that tube investigated broken at elbow position (Figure 1,3 , and 5) where this tube is bended and welded, therefore this position has higher residual stress compared to other position, and the flow of medium give higher dynamic load due the change of flow direction. All of these factors, fabrication defects, welding, bending, corrosive agents have significant contribution to the cause of failure to water wall tube of the boiler investigated ${ }^{9}$.

\section{CONCLUSION}

From all of examinations and tests result and the evidence that are obtained it can be concluded that the tube investigated has material in accordance with ASTM A 210 Grade C specification standard. However, some other evidence show that combination of fatigue and corrosion are the main contributor to the failure of water wall tube investigated. The position of crack initiation is on the elbow, because this location has higher tensile residual and operational stress than other location. Residual stress on the elbow generated from welding during installation, manufacturing defect of tube in the form of notch on the tube surface and bending process of the tube. While operational stress generated from the change of media flow direction in the elbow which give high dynamic load. At the same time corrosive agent is easy to stick in the elbow position. With this condition, crack could be formed at the elbow and then propagated side by side with corrosion reaction until the tube break.

\section{AUTHOR CONTRIBUTIONS}

Main contributor of this work is: Amin Suhadi. The other authors: Eka Febriyanti and Laili Novitasari are supporting contributors.

\section{ACKNOWLEDGMENT}

We would like to thank Mr. Sudarmadi as the head of B2TKS and Mr. Kirman as head of Laboratory for permission to use laboratory and their guidance.

\section{REFERENCES}

1. Liu, S.W., et al., "Failure Analysis of The Boiler Water Wall Tube", Case Studies in Engineering Failure Analysis, 9, 2017, p 35-39.

2. French, D.N., Metallurgical Failures in Fossil Fired Boilers, Willey and Sons Inc., 1993.

3. Fadjiga, G., M.Sraml, "Fatigue Crack Initiation and Propagation under Cyclic Contact Loading", Engineering Fracture Mechanics, 76, 2009, p1320-1335.

4. Cheng, W, et al., Micromechanics Modelling of Crack Initiation under Contact Fatigue, ASME J. Tribology, 1994.

5. Wilby, A.J., and Neale D.P., Defects Introduced Into Metals during Fabrication and Service, Materials Science and Engineering Vol. III, 2013.

6. Ahmad J., and Purbolaksono, J., "Hydrogen Damage in a Rear Riser Water Wall Tube of a Power Plant", Engineering Failure Analysis, 17, 2014, p1239-1245.

7. Schijve, J, Chapter 16: Corrosion Fatigue, Fatigue of Structure and Materials, 2014.

8. Larossa, N.A., et al., "Corrosion Fatigue: A review of Damage Tolerance Models", International Material Reviews, 2017.

9. Sangid M.D., "The Physics of Fatigue Crack Initiation", International Journal of Fatigue, 57, 2013, p58-72. 